\title{
Licensing Services in the Capital Investment Services and Integrated One Door Service (Dpmptsp) Banda Aceh City
}

\author{
Cut Putri Ellyana ${ }^{1}$, Ismail ${ }^{2}$ \\ ${ }^{I}$ Postgraduate Students of Iskandar Muda University \\ ${ }^{2}$ Lecturer at Iskandar Muda University
}

\begin{abstract}
Integrated Service Officers and licensing carry out their work based on Standard Operating Procedures (SOP) that apply to meet community expectations. Desired expectations in the future for Licensing Services are related to adequate facilities, infrastructure / service facilities, customer knowledge or abilities, good technical skills, attitudes and behaviors of officers to realize one-stop service properly, it is necessary to maintain the service supervision function licensing both internally and externally. The purpose of the research is to describe the licensing service procedures at the Banda Aceh City investment and integrated services office (DPMPTSP) as well as analyze the function of supervision of licensing services at the Capital Investment and One Stop Integrated Services Office (DPMPTSP) of Banda Aceh City. In this case the researchers used various theories to analyze the results of various research findings using a qualitative approach. Researcher data collection is done by observation, interview and also document analysis. Researcher observation data obtained from the treatment, while other information researchers dug through interviews with informants. To convince researchers, also analyzed the documents that exist at the Banda Aceh City Investment and Integrated Services Office (DPMPTSP). The results showed the standard components of licensing services such as facilities, infrastructure / service facilities were still not optimal. Relating to the attitude and behavior of officers, showing openness in conducting services. Then the licensing service supervision function has not been running optimally because it has not been done directly and routinely by supervisors in controlling subordinates. Likewise, the oversight of the DPR and the public is also poor.
\end{abstract}

Keywords

Integrated services; Licensing

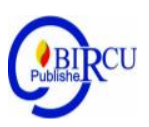

\section{Introduction}

Licensing is required by individuals and groups of business actors as legality, both in the form of licenses and business registration certificates (TDU). In this case, the organizing organization needs to socialize various information systems relating to the type of service, technical requirements, mechanisms and stages of administration, tracking the position of documents in each process, costs and completion times as well as the procedures for complaints so that the implementation of licensing services takes place effectively and efficiently, especially at the Banda Aceh City One-Stop Investment and Integrated Services 
office. This assumption as a vehicle for organizing, supplying and disseminating information systems as referred to in article 21 paragraph (2) of the Banda Aceh City Qanun Number 4 of 2010 concerning the operation of licensing and non-licensing services states that "Provision and dissemination of the information system is carried out clearly by the organizing organization through various media that is easily accessible and known by the public ". This shows the need for widespread and integrated information dissemination related to the service mechanism provided to business actors.

Integrated services and licensing in carrying out tasks based on Standard Operating Procedures (SOP) in accordance with technical policies in the field of public services and licensing services to the public which so far have not been in line with the expectation of timely, appropriate, correct, targeted and precise permit services. In administering licensing and non-licensing services, service organizations are required as mandated by Article 18 of the Banda Aceh City Qanun Number 4 of 2010 concerning the provision of licensing and non-licensing services, stating that "Organizing organizations are obliged to prepare and set service standards with due regard to community needs and environmental conditions". Desired expectations in the future for Licensing Services at the One Stop Investment and Integrated Services Office (DPMPTSP) relate to adequate facilities, infrastructure / service facilities, customer knowledge or abilities, technical skills, attitudes and behavior of officers.

For the sake of the realization of a one-stop service properly, it is necessary to maintain the function of licensing supervision services both internally and externally. Internal Supervision is carried out by superiors on a regular and continuous basis and functional supervision is needed to comply with plans and legislation in force. While external supervision can be carried out by the legislative body or directly by the public. The results of the supervision need to be conveyed orally or in writing to interested government officials in the form of contributions of ideas, suggestions, ideas. Observation results show licensing services at the Investment and Integrated Services One Door Service (DPMPTSP) shows the weakness of the standard components of licensing services related to facilities, infrastructure / service facilities as well as knowledge owned by service providers and also still low, the function of supervision of licensing services both in terms of internal or external. Weak internal oversight because the leadership does not routinely supervise the activities of the organization as an act of subordinate control. Meanwhile, external oversight is weak because there is no oversight from the legislative body or the public in a structured and massive manner.

\section{Review of Literature}

\subsection{Theory of Public Policy Implementation}

Public policy as a government action in achieving the goals or objectives that have been set. In this case the policy carried out by the government is related to whatever the government's choice to continue or not to do. Government policies made by government agencies to support the smooth running of the organization. According to David's view in Subarsono (2012) that "The government makes public policy, at the same time the government allocates values to the community because every policy contains a set of values in it". If the government policy is immediately made to contain values that are contrary to the values that live in society, then government policy will be challenged when implemented, and vice versa if a policy is made by the government as a public policy must be able to accommodate values and practices those practices that live and thrive in society. 
Policy is the responsiveness of public services regarding aspects of the formulation and implementation of public policies and the process of public management, both of which relate to society, the values that develop the need for excellent service of opinions and available choices. to achieve this goal, workers suggest ideas about flexibility, entrepreneurship, and a better willingness to adopt new, more creative ideas(Andrews \& Van de Walle, 2013). If government policy is right on target, then the main possibility is that the main problem lies in the community itself (Dewi in Halik, 2020)

The implementation of public policy as getting the job done and doing it, in carrying out policy implementation so as to require conditions including people or executors, money, and organizational skills. Likewise, the understanding of policy from various expert understandings as Santosa (2012) states that "Re-analyzing that public policy has key objectives, values and practices. Anderson in Santosa (2012) defines as follows "Public policy as a policy set by government agencies and officials. It is realized or not realized that public policy can be influenced by actors and factors from outside the government. But in the view of David Easton when the government makes policies to the community, because each policy contains a set of values in it.

\subsection{Service Theory}

Services as the activities of a person or group of people in an organization. Ratminto defines service as "an activity or series of activities that are invisible (cannot be touched) that occur as a result of interactions between consumers and employees or other things provided by service providers to solve customer / customer problems". Meanwhile Soetopo in Napitulu (2013) defines service as "An effort to help prepare what others need". In an opinion as Boediono (2013) states that "Service is a process of assistance to others in certain ways that require sensitivity and interpersonal relationships in order to create satisfaction and success". And public service according to Sinambela in Articleong (2013) states as follows: Every activity carried out by the government of a number of people who have every activity that is beneficial in a collection or unity and offers satisfaction, even though the results are not related to a physical product.

Public services are the provision of services often related to the elements of the service itself either by the government, the private sector, the community without meaningful payment to meet the needs of the community, so services are often also referred to as services, namely services. The services referred to herein as Santosa (2012) state that "Services that are marketed by business or professional companies with a motive for profit or commercial services". This is as Sedarmayanti (2014) states that "Community service is an effort made by a person and / or group of people or certain agencies to provide assistance and convenience to the community in achieving its goals".

Service quality and service innovations has a positive and significant impact on competitive advantage. Retail Quality of service is divided into five main indicators, namely physical aspect, reliability, personal interaction, problem solving and policy. Service innovation is technology, new service, interactions with customer's and service delivery system. Competitive advantage is divided into price/cost, quality, value to customer and product variety. (Kusumadwi, 20109)

Based on the above understanding of services / services which constitute every action or activity that can be offered by one party to another party, but basically is intangible and does not result in any ownership, so that the intangible and quickly disappear, but more can be felt than owned, but consumers can more actively participate in the process of consuming these services. The types of services provided by service units are in the form of providing and or processing physical tangible materials including distribution and delivery and direct 
consumers (units or individuals) that are in a system. In general, every person who produces a tangible final product can provide added value directly to the user in the form of a "permission service". In article 21 paragraph (1) Banda Aceh City Qanun number 4 of 2010 concerning Operation of Licensing and Non-Licensing Services.

The Organizing Organization shall provide and disseminate information systems relating to:

a. Types of services and technical requirements;

b. Mechanism and stages of management;

c. Tracking the position of documents in each process;

d. Costs and completion times; and

e. Procedure for complaints.

\subsection{Theory of Human Resources}

In the theory of Human Resources (HR) Human resources as the main source and assets in the organization so that in every task implementation is of course very important where in general, in an institution both government and private, where in carrying out the duties and functions required quality human resources, as according to Werther and Davis in Sutrisno (2013), states that "human resource planning is a systematic planning of the estimated needs and procurement of employees, which is known in a process that the planning of human resources".

Human resources must maximize the capability of varied human resources to support the development of resource accessibility. Thus, it is necessary to self-introspection that the most important part of increasing the value of human resources is to utilize all the talents of the people in the organization and take the best of a varied population outside the organization of public service delivery in the form of permit services. Likewise, the development of human resources contained in government on the one hand requires quality human resources which will certainly make the regional organization triumph on the other side of the country's economy, will move forward with the triumph of a government organization. In the increasingly open development and competition of global organizations, human resource management should not be forgotten because it is an optimal management of people within the organization so that the organization's performance is as expected. Assumptions born from human resource management indicate that humans have reason, feelings, desires, abilities, skills, knowledge, encouragement, power and intention. All of these potentials influence the organization's efforts in achieving its goals.

Hasibuan (2012) states as follows: Human Resources (HR) is the potential that exists in humans to realize their role as adaptive and transpormative social beings who are able to manage themselves and all the potential in them towards achieving the welfare of life in a balanced order and sustainable. Sedarmanyati (2014) states as follows "Human resources (HR) is a policy and practice determines aspects of human or human resources in management positions, which are intended to recruit, filter, train, reward and assess". This human resource as one of the organizational resources which has an important role in achieving its goals, therefore the importance of the role of humans in short-term and longterm competition because it has more value compared to other resources.

In this theory, prioritizing human resources as competitive superior in the organization so that the opinion of Wilson (2012) states that "A way related to human resources in order to become a source of competitive advantage is through increasing human capital (human capital) to be able to recognize and adapt to an ever-changing environment. " 


\subsection{Organizational Theory}

The organization is a collection of individuals who are in institutions and governments, where within the individual there are differences from one another with dimensions that include culture, values, education, gender, marital status, age, occupation and so on ". In achieving common goals effectively requires a good management, and correct, in using resources, then the problem tends to arise again management power is very important in an organization, where in achieving an organizational development it needs the role of all parties in its implementation there various kinds of work so coordination is needed so that these activities can take place properly.

The main element of organizational structure is differentiation which is the process of forming and supervising the division of labor or the level of specialization within the organization, while integration is the process of coordinating various tasks, functions, and divisions so that they can work together and achieve the same goals. Barrnard in Purwanto (2013 :) states that the organization as a system that consciously coordinates the activities carried out by two or more people. In this view, there are 3 (three) basic elements which are defined as:

a. Communication network;

b. Coordination system; and

c. People who work together in achieving the goals of the Organization.

\subsection{Monitoring Theory}

In the world of work, supervision is needed to control various activities carried out by the organization in implementing a government program in the institution by moving people, so we need supervision as Serdamanyanti (2014) states that "Supervision is a form of observation that is generally carried out as a whole make a comparison between those in the contract and what should be done, while the term control is a breakfast of the terms in the English control in an action that occurs ". Supervision of the delegation of authority for licensing services needs to be carried out because it involves the interests of many people and the needs of various parties both the government, institutions and the people required by the permit and the community in general. In this activity to be able to control the program of activities in accordance with careful planning, especially critical thinking and problem solving (critical thinking and problem solving) through dassaint and dessolend. In general the implementation of a good and planned supervision as expected by the participation of all existing components in the form of internal and external supervision.

Internal control system is an integral process of actions and activities carried out continuously by the leadership and all employees to provide adequate confidence in the achievement of organizational goals through effective and efficient activities, reliability of financial reporting, security of state assets and compliance with laws and regulations. . As a preparation for supervision, supervisory auditors are conducted to maintain the stability of the workload, not to neglect negative thinking, but to be oriented to positive thinking, therefore the role of supervision is very important, in carrying out routine tasks both financial, in goods and institutional services.

To further understand supervision, it is better as Suadi (2014) points out as follows: Supervision is the fourth managerial function after planning, organizing and directing. As one of the functions of management, supervision mechanism within an organization is absolutely necessary, where the implementation of a plan or program without being accompanied by a good and continuous supervision system, obviously will result in slow or even the achievement of the goals and objectives that have been determined. The purpose of 
supervision is carried out in conjunction with the auditing of auditors to support the government's efforts to, the management of permit delegation services.

Supervision as Handoko views in Ilham (2016) states that "Supervision is a process to ensure that organizational and management objectives are achieved". Whereas Brantas in Ilham (2016: 97) states that "Supervision is the process of monitoring, evaluating and reporting on the achievement of the goals set for corrective action for further improvement". Likewise, the government is striving to make every effort to realize the implementation of regional government that is clean and free of corruption, collusion and nepotism by guiding and supervising the administration of the government in delegating the authority of Capital Investment Licensing Services and One Stop Integrated Services in maintaining the territorial integrity of the Unitary State Republic of Indonesia.

\section{Research Method}

To get an overview of permit services at the Banda Aceh City Investment and One Stop Integrated Services Office, researchers used a qualitative approach. Referring to the idea put forward by Soetandyo (2013) related to a qualitative approach that "Qualitative methods are developed to study human life in limited cases, casuistic in nature, but deep (in depth) and total / holistic, in the sense of not knowing conceptual selection of symptoms into exclusive aspects that we recognize by variables.

In line with this study from various logical and easy-to-digest considerations in the minds of many people, this qualitative research can be synthesized again as Moleong (2014) views as follows: Qualitative research is research that aims to understand phenomena about what is experienced by research subjects for example behavior, perception, motivation, action and others holistically and by means of description in the form of words and language, in a special natural context and by utilizing various natural methods. Likewise, the view of Koentjaraningrat (2013) states that "qualitative research aims to develop precisely an individual trait, condition, symptoms or certain groups and or determine the frequency or spread of a symptom in society".

The research location was concentrated in the Banda Aceh City Investment and One Stop Integrated Services Office, with the following considerations:

1. The Banda Aceh City One-stop Investment and Integrated Service Office, as an official city government agency that carries out the duties of one as a permit service while simultaneously carrying out the principle of decentralized decentralization task in the work area in carrying out development services from the delegation of authority of the Banda Aceh City government in the permit as a permit. SKPK;

2. The One-Stop Investment and Services Office of Banda Aceh City, located in the center of the city with the location of this study basically the community is easier to reach to complete the required permits with reliable services;

3. The Banda Aceh City One-stop Investment and Integrated Service Office, as a research location, was selected in an effort to observe, explore and search for data and information and field facts as an explanation of the delegation of permit service authority to the Banda Aceh City investment and integrated services office.

Research informants were chosen deliberately or better known as purposive sampling, in order to dig up information and find data that forms the basis of theoretical design in the field of research that is still being carried out at the Banda Aceh City Investment and Integrated Services Office. Informants in this study consisted of the Head of DPM-PTSP, Secretary, Head of Investment, Head of Sub Department of Licensing and Non-Licensing Head of Complaints on Information and Reporting. 
Researcher data collection includes 3 (three) ways, as follows:

a. In-depth Interview (Indepth Interview).

The interview is an attempt to gather information by asking a number of questions verbally to be answered verbally also by the resource person. In this interview the researcher did not carry out with a strict structure, but with questions that increasingly focused on the desired problem so that the information collected was quite in-depth with the informants who had been determined. This was deliberately done so that the informants were not too bound, fixated and rigid in providing input but sought that the honesty of the informant researchers to provide accurate information was still true.

\section{b. Documentation Analysis.}

Documentation analysis as one of the qualitative data collection methods by viewing or analyzing documents created by the subjects themselves on the subject so that the documentation analysis technique is carried out in order to obtain secondary data carried out by collecting data sourced from the archives and documents available at each (object) at the study site.

\section{c. Direct observation (passive participation).}

Direct observation (passive participation) is a technique for observing and recording systematic data on the symptoms studied. Direct observation is one of the collection techniques used by researchers to formally observe a variety of activities both in planning, implementation, accountability and / or evaluation including documents used as guidelines.

\section{Discussion}

The Banda Aceh City Investment Board and One Stop Integrated Service (DPM-PTSP) was formed as a manifestation of the Banda Aceh City Government's goal of realizing good governance by improving the quality of public services through simplifying the bureaucracy, so as to create a clean, accountable and transparent government figure especially in the field of licensing and non-licensing. To realize excellent public services especially in the areas of licensing and non-licensing, the Banda Aceh City Government established the One-Stop Integrated Licensing Service Office (KPPTSP) of Banda Aceh City on February 20, 2007 through the decision of the Banda Aceh Mayor Number 378 of 2006 concerning Formation of Organizations and Procedures Work of the One Stop Integrated Service Office in Banda Aceh City.

On December 31, 2016, there was a change in the Organizational Structure and work procedures of the Banda Aceh City Integrated One-Stop Licensing Services Office into the One-Stop Investment and Service Office (DPM-PTSP) of Banda Aceh City through the Banda Aceh Mayor Regulation Number 56 of 2016 concerning Composition , Position of Duties and Functions, Authority and Work Procedures of the One-Stop Investment and Integrated Services Office. Efforts to reform the Government's bureaucracy, especially to improve the quality of public services, DPM-PTSP Banda Aceh City seeks to simplify service procedures in the field of licensing and non-licensing by placing the entire licensing process in an integrated manner at one door in one office, so that the processing procedures become easier, faster, transparent and guarantee certainty of service quality, more professional management, which leads to better service quality and oriented to the needs and satisfaction of the community and business people, able to compete and compete in an era of 
globalization which is full of challenges. In addition to utilizing and implementing the development of science and information technology for integrated data and information management in the One Door Management Information System (SIMSATU) application. SIMSATU or One Door Management Information System is a work system that is built by applying information technology in managing data and information on licensing and nonlicensing from input, validation, processing, presentation and publication of data \& information quickly, precisely, and accurately to increase public satisfaction and business actors with the principle of efficient licensing services.

In 2015 an online licensing service information system was also implemented. The purpose of developing the Online Licensing Information System is the realization of data management and licensing and non-licensing information that is integrated in a central / efficient and effective data center / manager, so as to simplify the licensing service process and accelerate the time for permit completion, as well as facilitate the community / business actors to access the data and information needed. The vision of the organization is to create a conducive investment climate through a one-stop integrated service to encourage the development of a more developed and competitive social economy. While the mission consists of:

a) Promoting a conducive investment climate and increasing investment opportunities;

b) Improve service quality through one-stop integrated services;

c) Encourage economic growth through the ease of licensing;

d) Develop information technology systems in the field of investment; and

e) Increase regional potential, investment promotion and cooperation.

In carrying out its vision and mission, DPM-PTSP Kota Banda Aceh is strengthened by 36 employees who work professionally. As a basis for carrying out their duties, employees assigned to the Banda Aceh KPPTSP according to their level of education can be seen in table 1.1 below :

Table 1. Employees at DPM-PTSP according to their education level 2019

\begin{tabular}{|l|l|l|}
\hline No. & Level of education & Number of Employees \\
\hline 1. & Strata II & 3 Peoples; \\
2. & Strata I & 12 Peoples ; \\
3. & Diploma IV & 2 Peoples ; \\
4. & Diploma III & 5 Peoples ; \\
5. & Senior High School & 13 Peoples ; \\
6. & Junior High School & 1 Peoples ; \\
\hline \multicolumn{2}{|l|}{ Total } & 36 Peoples ; \\
\hline
\end{tabular}

Source: DPM-PTSP of Banda Aceh City in 2019

Then the results of the study related to the licensing service standard component in the Office of Investment and Integrated Services One Door (DPMPTSP) of Banda Aceh City showed that public services were able to provide services perfectly, but the ingredients were still considered to be inadequate because of the presence of service spaces, work desks and Air Conditioner / AC is less available overall. Service providers have the ability to carry out their duties. Knowledge of service personnel as a very important part in maximizing the service process.

In an implementation that is carried out if you do not have enough knowledge will make a policy not run well and in accordance with the expectations of many people where in every program that is run of course in need of good knowledge so that all programs that are run in accordance with what is in wanted by many people. Broadly all programs that are run 
will not run optimally and well, if not done as desired and expected by many parties. The results of the study also showed the existence of skills so that it had positive implications in conducting services

The technical skills of service personnel as individual responsiveness to competencies possessed so as to be able to contribute to the establishment, structuring, placement are far more rational and not too cause a great social psychological turmoil both for agencies and personal. Every government institution has a procedure at least once in an effort to improve employee performance, because after all the forms and any kind, certainly need a guide to carry out the duties and functions of each element or work unit. Standard Operating Procedure (SOP) is a system designed to facilitate, tidy up and order the work. The results of the study relate to the attitude and behavior of good officers who can make changes in the way of thinking, attitudes, behavior that they educate. With its strengths, which are excess knowledge and experience, the apparatus develops highly disciplined.

Related to supervision is an important activity so that the administration of government can achieve its objectives effectively and efficiently. The aspects of the principles of effectiveness and effectiveness in carrying out functional Supervision work consists of Supervision conducted by the Head of the Investment Office and the One Stop Integrated Licensing Service (DPM-PTSP) of Banda Aceh City. Based on this assessment, it can be found that there are influences either in the form of wealth or state finances in the form of waste and / or leakage, or those that have no direct effect. The results showed that all examinations carried out by the functional supervision apparatus in principle used the lines of the management control system to find out the supervision was running properly. Supervision of Public Services, at the One-Stop Integrated Investment and Licensing Service Office (DPM-PTSP) of Banda Aceh City, needs to be fostered and supervised in order to be able to carry out their functions optimally in accordance with established service standards by prioritizing public services at the Integrated Investment and Licensing Services Office One Door (DPM-PTSP) Banda Aceh City.

The role of service is very beneficial and decisive, when all activities that are engaged in the marketing of services in the community do competition to capture the market and consumer attention. Competency of human resource improvement services where if there is insufficient knowledge, it will result in not running optimally, a program run by the One-Stop Integrated Investment and Licensing Services Office (DPM-PTSP) of Banda Aceh City, where knowledge is a very important part in maximize a process in the goals to be achieved by the Office of Investment and Integrated Licensing Services of One Door (DPM-PTSP) Banda Aceh City, where good knowledge will make a good change also for the process in a development itself, which in a implementation carried out if you do not have enough knowledge will make a policy not run well and in accordance with the expectations of many people where in every program that is run of course in need of good knowledge so that all programs run according to what is desired by many communities, in a manner the extent to which all programs run will not run optimally and well, if not done as desired and expected by many parties, here is another at the Investment Office and the One Stop Integrated Licensing Service (DPM-PTSP) Banda Aceh City as the party most responsible, must carry out all that in accordance with what is expected by many parties, in carrying out the desired goals. Supervision of the delegation of authority for licensing services needs to be carried out because it involves the interests of many people and the needs of various parties the government, institutions and the people required by the permit and the community in general. 


\section{Conclusion}

Licensing service standard components at the Banda Aceh City Investment and One Door Integrated Services Office (DPMPTSP) such as facilities, infrastructure / service facilities have not been maximized, relating to buildings, work desks and other equipment that supports the work of service personnel feels uncomfortable if the size and the form is adjusted according to the posture of each employee. Do not let the tables and chairs that are supposed to be used and used for work actually cause employees to be lazy because it is too uncomfortable, air conditioning, a tool to cool and cool the air in a closed room. AC is needed. Attitude and Behavior of Officers, Open Behavior (overt behavior) Open behavior occurs if the response to the stimulus is in the form of actions or practices that can be observed by others, Employees in the Investment Office and the One Stop Integrated Service (DPMPTSP) of Banda Aceh City lack a pregnant attitude aspects of evaluation or evaluative of objects and have intellectual aspects related to emotional aspects.

The licensing service supervision function at the Capital Investment Office and the One Stop Integrated Service (DPMPTSP) in Banda Aceh City is not running as well as internal control and routine supervisory direct supervision of the organization's activities as a subordinate control is not done. Also the weak functional supervision carried out on the implementation of services in accordance with statutory regulations. External Oversight is not yet running the supervision of the community in sharing government activities even though it is in the form of ideas and innovative weaknesses of DPRK supervision of government implementation, development and social services.

\section{References}

Boediono. (2013). Ekonomi Makro. Yogyakarta: BPFE-Yogyakarta.

Hasibuan. (2012). Manajemen Sumber Daya Manusia. Jakarta: PT Indah Lestari.

Halik, dkk. (2020). The Effect of Administrative Implementation Principles towards the Effectiveness of Government Services. Budapest International Research and Critics Institute (BIRCI-Journal), P. 255-261

Ijan. (2014). Manajemen Pelayanan. Jakarta: Yapana

Ilham . (2016). Pengaruh Gaya Kepemimpinan Terhadap Motivasi. Malang: PT. Indolakto Factory Pandaan.

Kusumadewi, R. (2019). Impact of Service Quality and Service Innovations on Competitive Advantage in Retailing, Budapest International Research and Critics Institute (BIRCIJournal), P. 366-374.

Moleong, Lexy J. (2014). Metodologi Penelitian Kualitatif. Edisi Revisi. Bandung: PT. Remaja Rosdakarya.

Pasalong. (2013). Kepemimpinan Birokrasi. Bandung: CV. Alfabeta.

Peraturan Menteri Dalam Negeri Nomor 24 Tahun 2014 tentang Pelayanan Publik,

Qanun Kota Banda Aceh Nomor 4 Tahun 2010 tentang Penyelenggaraan Pelayanan Perizinan dan Non Perizinan.

Sadhana, Kridawati. (2014). Realita Kebijakan Publik. Malang: Penerbit Unmer. (UM-Press). Santosa. (2012). Administrasi Publik (Teori dan Aplikasi Good Governance), Bandung: PT. Refika Aditama.

Sedarmayanti. (2014). Manajemen Sumber Daya Manusia, (Reformasi Birokrasi dan Manajemen Pegawai Negeri Sipil), 2014. Bandung: PT. Refika Aditama.

Soetanyo. (2013). Metode Penelitian Kualitatif. Bandung: Remaja Rosdakarya. 
Suadi, Amran. (2014). Sistem Pengawasan Badan Peradilan di Indonesia. Jakarta: PT. Raja Garfindo Persadas.

Subarsono. (2012). Analisis Kebijakan Publik (Konsep, Teori dan Aplikasi). Yogyakarta: Pustaka Pelajar.

Sugiyono. (2012.) Metode Penelitian Kualitatif. Bandung: Alfabeta.

Sutrisno, Hadi. (2012). Sumber Daya Manusia. Jakarta: Remaja Rosdakarya.

Wilson. (2012). Sumber Daya Manusia. Jakarta: Alfabeta. 